Public Health

\section{Chewing the fat}

\section{on trans fats}

Background and epidemiology: Trans fatty acids, or trans fats, are unsaturated fats produced through partial hydrogenation, when vegetable oils are heated in the presence of metal catalysts and hydrogen. ${ }^{1}$ Hydrogenation increases the shelf life and stability of fatty acids and foods containing them. During partial hydrogenation, some double bonds between carbon atoms remain but may shift to a different position along a chain and alter their configuration from cis to trans fats.

Trans fats are present in many food products, including vegetable shortening, margarines, baked goods, snack foods, fried foods, salad dressings and many processed foods. Low levels are also found in dairy products, lamb and beef fat, because small amounts of trans fat are produced in the gastrointestinal tract of ruminants.

As much as $22 \%$ of the average intake of trans fats by Canadian adults is provided by foods consumed away from home. ${ }^{2}$ The intake of trans fats has been shown to increase the risk of heart disease by raising low-density lipoprotein (LDL) cholesterol levels and lowering high-density lipoprotein (HDL) cholesterol levels. This com- bined effect on LDL and HDL cholesterols is double that of saturated fatty acids. ${ }^{3}$ The effect on triglyceride and $\mathrm{Lp}$ (a) lipoprotein levels is also greater than that of saturated fats; high blood levels of $L p(a)$ lipoprotein have been independently linked with an increased risk of coronary artery disease (CAD). Trans fats may also have other adverse effects on thrombogenesis through altered prostaglandin balance. ${ }^{4}$ Results of large cohort studies have shown increased relative risks for $\mathrm{CAD}$ with high trans fat intake (Table I). There have been no safe limits of trans fat consumption shown.

Prevention: Some countries have effectively imposed a ban on trans fats (e.g., Denmark has banned oils and fats that contain more than $2 \%$ trans fats). In Canada, Health Canada and the Heart and Stroke Foundation of Canada have formed a task force to address trans fat consumption that will target public education, food labelling and ways for the food service and food-processing industries to reduce the use of trans fats. In addition, guidelines are being developed for the provision of nutrition information by chain restaurants to customers, and restaurants are requested to use modified recipes and ingredients containing lower amounts of trans fats.

International harmonization of nutrition labelling regulations is also be-

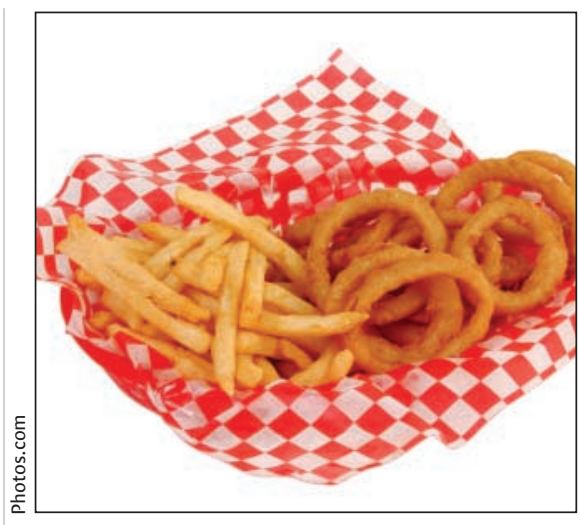

ing addressed. Companies importing food products do not currently have to follow the same labelling regulations as manufacturers of food products in Canada. For example, a "trans-free" product in Canada must contain less than $0.2 \mathrm{~g}$ of trans fat per serving and must also be low in saturated fats; in the United States, the limit of trans fats is $0.5 \mathrm{~g}$. Compliance with nutrition labelling regulations by most food manufacturers in Canada and companies wishing to import food products is required by Dec. I2, 2005; small companies will have until Dec. 12, 2007, because of reduced capacity to meet the regulations.

Product labelling of trans fat content is expected to make a difference: the regulation issued in 2003 by the US Food and Drug Administration requiring that manufacturers list trans fats on the labels of food products and

Table 1: Examples of cohort studies examining trans fat consumption and coronary outcomes

\begin{tabular}{|c|c|c|}
\hline Study* & Subjects & Study findings \\
\hline Oh et al & $\begin{array}{l}78778 \text { women without } \\
\text { CVD or DM }\end{array}$ & $\begin{array}{l}\text { RR for CAD was } 1.33(95 \% \mathrm{Cl} 1.07-1.66) \text { among } \\
\text { women in highest } \mathrm{v} \text {. lowest quintile of trans fat } \\
\text { intake }\end{array}$ \\
\hline $\begin{array}{l}\text { Oomen } \\
\text { et al }\end{array}$ & $\begin{array}{l}667 \text { men aged } \\
64-84 \text { yr without CAD }\end{array}$ & $\begin{array}{l}\text { RR for CAD was } 2.00(95 \% \mathrm{Cl} 2.07-3.75) \text { in highest } \\
\text { v. lowest tertile of trans fat intake }\end{array}$ \\
\hline $\begin{array}{l}\text { Pietinen } \\
\text { et al }\end{array}$ & $\begin{array}{l}21930 \text { men aged } \\
50-69 \text { yr without CVD } \\
\text { who smoked }\end{array}$ & $\begin{array}{l}\mathrm{RR} \text { for coronary death was } 1.39 \text { ( } 95 \% \mathrm{Cl} 1.09-1.78) \\
\text { in highest } \mathrm{v} \text {. lowest quintile of trans fat intake } \\
\text { (median } 6.2 \mathrm{v} .1 .3 \mathrm{~g} / \mathrm{d} \text { respectively) }\end{array}$ \\
\hline $\begin{array}{l}\text { Aschiero } \\
\text { et al }\end{array}$ & $\begin{array}{l}43757 \text { men aged } \\
40-75 \text { yr without CVD } \\
\text { or DM }\end{array}$ & $\begin{array}{l}\text { RR was } 1.40(95 \% \mathrm{Cl} 1.10-1.79) \text { for nonfatal } \mathrm{MI} \text { and } \\
1.78(95 \% \mathrm{Cl} 1.11-2.84) \text { for fatal CAD among men } \\
\text { in the highest } \mathrm{v} \text {. lowest quintile of trans fat intake. } \\
\text { After adjustment for fibre intake, the respective } \\
\text { RRs were } 1.63(95 \% \mathrm{Cl} 1.01-2.62) \text { and } 1.41(95 \% \mathrm{Cl} \\
0.86-2.32)\end{array}$ \\
\hline
\end{tabular}

Note: $\mathrm{CAD}=$ coronary artery disease, $\mathrm{Cl}$ = confidence interval, $\mathrm{CVD}=$ cardiovascular disease, $\mathrm{DM}=$ diabetes mellitus, $\mathrm{MI}=$ myocardial infarction, $\mathrm{RR}=$ relative risk,

*Oh et al Am J Epidemiol 2005;161(7):672-9. Oomen CM et al Lancet 2001;357:746-51. Pietinen et al Am J Epidemiol 1997;145:876-87. Aschiero A et al BMJ 1996;313:84-90. 
some dietary supplements is expected to prevent 600 to 200 cases of CAD and 250 to $500 \mathrm{CAD}$-related deaths each year. ${ }^{5}$

Practice implications: There have been no safe levels of trans fat consumption shown, and dietary trans fat and saturated fat intake should be reduced. Consumers should take advantage of the new labelling regulations and select products that contain low levels of trans and saturated fats.

\section{Sally Murray \\ Ken Flegel \\ CMAJ}

\section{REFERENCES}

I. Katan MB, Mesink RP, Zock PL. Trans fatty acids and their effect on lipoproteins in humans. Annu
Rev Nutr 1995;15:473-93.

2. Interim report of the Trans Fat Task Force. Ottawa: Health Canada; 2005. Available: www.hc-sc.gc.ca /fn-an/nutrition/gras-trans-fats/tftf_interim_report _rapport_preliminaire_e.html (updated 2005 Aug I6; accessed 2005 Sept 7).

3. Mensink RPM, Katan MB. Effect of dietary trans fatty acids on high-density and low-density lipoprotein cholesterol levels in healthy subjects. $N$ Engl J Med I990;323:439-45.

4. Wahrburg U. What are the health effects of fats? Eur J Nutr 2004;43(Suppl I):I/6-I/II.

5. FDA acts to provide better information to consumers on trans fats. Rockville (MD): US Food and Drug Administration. Available: www.fda.gov /oc/initiatives/transfat/ (accessed 2005 Sept 7).

\section{IN THE LITERATURE}

\section{Do ASA and NSAIDs reduce}

\section{the risk of colorectal cancer?}

Chan AT, Giovannucci EL, Meyerhardt JA, et al. Long-term use of aspirin and nonsteroidal anti-inflammatory drugs and risk of colorectal cancer. JAMA 2005;294(8):914-23.

Background: Regular use of ASA in patients with a history of colorectal adenoma or cancer has been shown to reduce the risk of recurrent adenoma within $\mathrm{I}-3$ years. ${ }^{1}$ Although 2 trials looking at the effect of ASA on colorectal cancer did not show a benefit after 5-Io years, ${ }^{2,3}$ it is unknown whether ASA taken for a longer duration, or at a different dose, would reduce the risk of colorectal cancer. It is also unclear

Table 1: Trend in relative risk of colorectal cancer by duration of regular ASA use*

\begin{tabular}{cc}
\hline $\begin{array}{l}\text { Years of regular } \\
\text { ASA use }\end{array}$ & $\begin{array}{c}\text { Adjusted RR } \\
(95 \% \mathrm{Cl}) \dagger\end{array}$ \\
\hline 0 & 1.0 \\
$1-5$ & $1.04(0.88-1.24)$ \\
$6-10$ & $0.89(0.74-1.08)$ \\
$11-20$ & $0.67(0.54-0.85)$ \\
$>20$ & $0.68(0.54-0.85)$ \\
\hline
\end{tabular}

Note: $\mathrm{RR}=$ relative risk, $\mathrm{Cl}$ = confidence interval. * Regular ASA use is defined as 2 or more $325-\mathrm{mg}$ tablets per week.

$\dagger p$ for trend $<0.001$. See Table 2 footnote for definition of multivariate adjustment. whether other NSAIDs would have similar protective effects.

Design: A prospective study involving 82 gII women enrolled in the Nurses' Health Study collected data from questionnaires biennially on ASA and other NSAID use and new cases of colorectal cancer from I980 to June 2000. From the data collected, the mean ASA intake was calculated, and women were divided into groups of regular ASA users ( 2 or more $325-\mathrm{mg}$ tablets per week) and nonregular users. Rates of colorectal cancer were calculated for each group by dividing the number of new cases of cancer by the number of person-years of ASA use. The investigators also collected data about gastrointestinal bleeding in participants.

Results: A total of 962 cases of colorectal cancer were found among the wo- men during the 20 years of follow-up. Regular users of ASA had a lower risk of colorectal cancer than nonregular users. The reduced risk started after Io years of regular use, and larger doses of ASA resulted in larger reductions in risk (Table I, Table 2). Women who used more than 14 tablets of ASA per week for longer than ro years had a $53 \%$ lower risk of colorectal cancer than those who did not use ASA (ageadjusted relative risk [RR] 0.47). A similar protective dose-response relation was found for NSAIDs: women who used NSAIDs regularly ( 2 or more tablets per week) had a $2 \mathrm{I} \%$ lower risk of colorectal cancer than nonregular users (adjusted RR 0.7I, 95\% confidence interval 0.64-0.97).

ASA and NSAID use were not related to reduced number of rectal cancers, and lower doses of ASA $(50 \mathrm{mg} / \mathrm{d})$ did not lower the risk of colon cancer.
Table 2: Trend in relative risk of colorectal cancer by ASA dose

\begin{tabular}{lcc}
\hline & \multicolumn{2}{c}{ Adjusted relative risk $(95 \% \mathrm{Cl})^{*}$} \\
\cline { 2 - 3 } $\begin{array}{l}\text { No. of 325-mg ASA } \\
\text { tablets per wk }\end{array}$ & $\begin{array}{c}\text { All women with } \\
\text { colorectal cancer† }\end{array}$ & $\begin{array}{c}\text { Women with history } \\
\text { of ASA use } \geq 10 \text { yrt }\end{array}$ \\
\hline 0 & 1.0 & 1.0 \\
$0.5-1.5$ & $1.10(0.92-1.31)$ & $0.94(0.79-1.13)$ \\
$2-5$ & $0.89(0.73-1.10)$ & $0.74(0.59-0.93)$ \\
$6-14$ & $0.78(0.62-0.97)$ & $0.81(0.63-1.05)$ \\
$>14$ & $0.68(0.49-0.95)$ & $0.51(0.33-0.80)$ \\
\hline
\end{tabular}

Note: $\mathrm{Cl}=$ confidence interval.

*Adjusted for age, smoking before age 30, body mass index, regular vigorous exercise, colorectal cancer in a parent or sibling, history of endoscopy, history of polyp, postmenopausal hormone use, current multivitamin use, frequency of beef, pork or lamb as a main dish per week, alcohol consumption, and folate and calcium intake. tp for trend $<0.001$. 